\title{
Effect of heat and microwave treatments on phenolic compounds and fatty acids of turmeric (Curcuma longa L.) and saffron (Crocus sativus L.)
}

\author{
Efeito de tratamentos térmicos e por micro-ondas em \\ compostos fenólicos e ácidos graxos de cúrcuma \\ (Curcuma longa L.) e açafrão (Crocus sativus L.)
}

\author{
Mariela Valentina Cortez ${ }^{1,2}$, Nilda Raquel Perovic ${ }^{1}$, Elio Andrés Soria ${ }^{2,3}$, \\ María Daniela Defagó ${ }^{1,2 *}$ (D) \\ ${ }^{1}$ Universidad Nacional de Córdoba, Facultad de Ciencias Médicas, Escuela de Nutrición, Centro de Investigación en \\ Nutrición Humana (CENINH), Córdoba - Argentina \\ ${ }^{2}$ Consejo Nacional de Investigaciones Científicas y Técnicas (CONICET), Instituto de Investigaciones en Ciencias \\ de la Salud (INICSA), Córdoba - Argentina \\ ${ }^{3}$ Universidad Nacional de Córdoba, Facultad de Ciencias Médicas, Instituto de Biología Celular, Córdoba - \\ Argentina
}

*Corresponding Author: María Daniela Defagó, Universidad Nacional de Córdoba, Facultad de Ciencias Médicas, Escuela de Nutrición, Centro de Investigación en Nutrición Humana (CENINH), De La Reforma Bv., Edificio Escuelas $\left(2^{\circ}\right)$, Ciudad Universitaria, 5014, Córdoba - Argentina, e-mail: danieladefago@outlook.com, easoria@fcm.unc.edu.ar

Cite as: Cortez, M. V., Perovic, N. R., Soria, E. A., \& Defagó, M. D. (2020). Effect of heat and microwave treatments on phenolic compounds and fatty acids of turmeric (Curcuma longa L.) and saffron (Crocus sativus L.). Brazilian Journal of Food Technology, 23, e2019205. https://doi.org/10.1590/1981-6723.20519

\begin{abstract}
Turmeric and saffron are spices with fatty acids and phenolic compounds that exert several human health benefits. Nonetheless, their bioavailability may be reduced by cooking that involves high temperatures. Thus, our aim was to evaluate the effects of domestic heat treatments with respect to untreated controls on these molecules assessed by spectrophotometry and gas chromatography: microwaving, boiling under pressure and boiling without it (compared by ANOVA, $p<0.05$ ). All treatments reduced phenolic compounds in saffron, whereas only microwaving decreased them in turmeric. Turmeric curcumin was reduced by microwaving and boiling under pressure. Turmeric and saffron showed a different fatty acid profile, which was differentially affected depending on the treatment. In conclusion, although the functional and nutritional quality of these spices can be affected, turmeric is more resistant to heat than saffron and shows a better lipid profile with high unsaturated fatty acids even after treated. Also, boiling preserved potential health-promoting phenolic compounds and some unsaturated fatty acids. Although a risk of bioactive compound loss exists, the correct cooking method can reduced it.
\end{abstract}

Keywords: Lipids; Polyphenols; Curcumin; Cooking; Saffron; Turmeric. 


\section{Resumo}

A cúrcuma e o açafrão são especiarias com ácidos graxos e compostos fenólicos que proporcionam vários benefícios para a saúde humana. No entanto, sua biodisponibilidade pode ser reduzida pelo cozimento, que envolve alta temperatura. Assim, objetivou-se avaliar os efeitos nessas moléculas comparando tratamentos térmicos domésticos com controles não tratados por meio de espectrofotometria e cromatografia gasosa: micro-ondas, fervura sob pressão e fervura sem pressão (comparado por ANOVA, $p<0,05$ ). Todos os tratamentos reduziram os compostos fenólicos no açafrão, enquanto na cúrcuma foram reduzidos apenas pelas micro-ondas. A curcumina da cúrcuma foi reduzida pelas micro-ondas e por fervura sob pressão. A cúrcuma e o açafrão apresentaram diferentes perfis de ácidos graxos, que foram diferencialmente afetados dependendo do tratamento. Em conclusão, embora a qualidade funcional e nutricional destas especiarias possa ser afetada, a cúrcuma é mais resistente ao calor do que o açafrão, e apresenta um melhor perfil lipídico com altos ácidos graxos insaturados, mesmo após os tratamentos. Além disso, a fervura preservou compostos fenólicos potenciais na promoção da saúde e alguns ácidos graxos insaturados. Embora exista um risco de perda de composto bioativo, este pode ser reduzido pelo método de cozimento correto.

Palavras-chave: Lípidos; Polifenóis; Curcumina; Cozimento; Açafrão; Cúrcuma.

\section{Introduction}

Turmeric (Curcuma longa L.) and saffron (Crocus sativus L.) have been broadly used as spices since ancient times to flavour and colour food, given their sensory properties. Several studies report their biological potential to protect against non-communicable diseases, such as cardiovascular dysfunction, cancer, and diabetes (Lai \& Roy, 2004; Moshiri et al., 2015; Shehzad et al., 2017).

Turmeric contains curcuminoids, water-soluble peptides, proteins and methionine residues with antioxidant properties (Di Lorenzo et al., 2013). Curcumin, a phenolic compound, is the main bioactive ingredient in the turmeric extract and is widely consumed as part of the curry mix and dietary supplements, which exhibit anti-inflammatory effects on health (Schneider et al., 2015; Yang et al., 2017).

Saffron contains crocin, a carotenoid responsible for the orange colour of this spice. Different studies also show other bioactive compounds with anti-cancer and anti-inflammatory activity (Zhang et al., 2013).

We have analysed both polyphenols and lipids in these unprocessed products to identify different promissory biologically-active compounds. Some chemopreventive molecules were found, such as some phenolic acids, kaempferol, and saturated and unsaturated fatty acids (Canalis et al., 2012).

Food processing plays a crucial role in quality, safety, storage, and final ingredient characteristics. Concerning this, heat-related chemical reactions involved in domestic cooking might compromise or alter these bioactive compounds and their properties. Curcuminoids, as examples, are susceptible to long drying time, high temperature, extraction, processing, and storage (Suresh et al., 2007; Choi et al., 2014). However, heat treatments exert controversial changes in crocin and safranal concentrations (Gregory et al., 2005; Sánchez et al., 2008; Rodríguez-Neira et al., 2014).

Therefore, the aim of this study was to evaluate phenol and fatty acid content in saffron and turmeric samples treated with different cooking methods.

\section{Material and methods}

\subsection{Spice processing}

Commercial samples of dried and powdered products were from different lots $(n=21): 0.2 \mathrm{~g}$ capsules of Spanish saffron (Cafés La Virginia SA ${ }^{\circledR}$ ) and $250 \mathrm{~g}$ packs of Indian turmeric (El Vallisto ${ }^{\circledR}$, Argentina). These spices were prepared in distilled water $(1 \mathrm{~g} / 100 \mathrm{~mL})$ and separately treated with three different methods: 
20 min boiling at $100{ }^{\circ} \mathrm{C}(\mathrm{B}), 10$ min pressurised boiling at $15 \mathrm{psi}$ and $120^{\circ} \mathrm{C}(\mathrm{BP})$ or $650 \mathrm{~W}$ during $1 \mathrm{~min}$ microwaving (MW), to simulate domestic cooking, with controls being untreated samples. Water content was equalised after sample freeze-drying for 24 hours at $\leq-70{ }^{\circ} \mathrm{C}$ and $\leq 1.33 \mathrm{~Pa}$, using a Thermovac device (Cortez \& Soria, 2016).

\subsection{Phenol determination}

Samples were extracted with methanol (Cicarelli, Argentina), for 24 hours at $4{ }^{\circ} \mathrm{C}$ in darkness $(1: 1$ volume relation), to quantify total phenols and curcumin in the extracted supernatants obtained by centrifugation at $5000 \mathrm{rpm}$ and $10{ }^{\circ} \mathrm{C}$ for $30 \mathrm{~min}$ (Canalis et al., 2012). All reactants were purchased from Sigma-Aldrich (USA), and readings were performed in a BIO-RAD Model 680 spectrophotometer (USA).

For total phenols, $25 \mu \mathrm{L}$ of supernatant were incubated during $30 \mathrm{~min}$ in darkness with $25 \mu \mathrm{L}$ of $2 \mathrm{~N}$ Folin-Ciocalteu reagent, $150 \mu \mathrm{L}$ of distilled water and $50 \mu \mathrm{L}$ of a saturated sodium bicarbonate solution. Then, reaction absorbance was determined at $750 \mathrm{~nm}$ to calculate $\mathrm{mg} / \mathrm{g}$ according to a standard curve of silymarin.

For curcumin, the absorbance of $100 \mu \mathrm{L}$ of supernatant was recorded at $415 \mathrm{~nm}$ to calculate the $\mathrm{mg} / \mathrm{g}$ of using a standard curve of this compound.

These procedures were performed according to previous work (Canalis et al., 2012).

\subsection{Fatty acid determination}

Lipids were extracted according to Foch's method. They were converted into fatty acid methyl esters by sodium methoxide treatment, which were separated using a gas chromatograph (Clarus 500 Perkin Elmer, USA), with a polar fused capillary column (BPX $70.30 \mathrm{~m}$ long, $0.25 \mathrm{~mm}$ ID, $0.25 \mathrm{um}$ film, Phenomenex, USA), split injector (split ratio: $50 \mathrm{~mL} / \mathrm{min}$ ) and flame ionization detector. The nitrogen flow was $20 \mathrm{~cm} / \mathrm{s}$ and $2{ }^{\circ} \mathrm{C} / \mathrm{min}$ gradient (oven program: $180^{\circ} \mathrm{C}$ to $240{ }^{\circ} \mathrm{C}$ ). Individual fatty acids were identified with external standards (Nu Check, USA), and their profile was expressed as a percentage of total detected acids. These procedures were performed according to previous work (Ramos Elizagaray et al., 2019).

\subsection{Statistical analysis}

Data were expressed as mean \pm standard error from separate experiments performed in quintuplicate. ANOVA models followed by the Turkey's test were used to compare phenolic compound means among treatments, while the Fisher's exact test was used to compare differences in proportions (dp) respect to control in case of fatty acid percentages (significant level of $p<0.05$ ), using the Infostat statistical software.

\section{Results and discussion}

In the present study, the content of phenols and fatty acids of saffron and turmeric were modified by the assayed treatments, which should be considered to develop nutritional recommendations.

Table 1 shows the total phenol concentrations of untreated and treated saffron and turmeric. Phenols from saffron were reduced by the three treatments (B, BP, and MV) compared with control, whereas only MW reduced these compounds in turmeric $(p<0.05)$. In saffron, this reduction is according to other researchers, who report that phenolic compounds, such as flavonoids, maintain their physicochemical integrity up to $90{ }^{\circ} \mathrm{C}$ (Serrano-Díaz et al., 2013) and after mechanical processes (Pujimulyani et al., 2012). Also, phenols are more susceptible to heat than other phytochemicals, such as carotenoids (Sánchez et al., 2011). In turmeric, the phenolic reduction by MW is in contrast with Khatun et al. (2006), who report an increase of phenol concentrations by convection cooking, which is attributable to differences in the heat source used 
by each research. Nonetheless, Jiménez et al. (2001) reported phenolic changes by MW and organoleptic modifications, due to inhibition of polyphenol oxidase enzyme.

Curcumin concentrations of turmeric were significantly decreased by MW $(5.98 \pm 0.61 \mathrm{mg} / \mathrm{g})$ and BP $(3.95 \pm 0.41 \mathrm{mg} / \mathrm{g}) \quad(p<0.05)$, which is concordant with Suresh et al. (2007), whereas B $(7.70 \pm 1.05 \mathrm{mg} / \mathrm{g})$ had no significant effect respect to control $(10.39 \pm 0.23 \mathrm{mg} / \mathrm{g})($ Table 1$)$.

Table 1. Phenolic compounds of saffron and turmeric after cooking treatments.

\begin{tabular}{|c|c|c|c|}
\hline Treatments & Compounds & Saffron & Turmeric \\
\hline \multirow{2}{*}{ Control } & Total phenols & \multirow{2}{*}{$20.33 \pm 0.51 \mathrm{mg} / \mathrm{g} \mathrm{a}^{\mathrm{a}}$} & $10.07 \pm 0.29 \mathrm{mg} / \mathrm{g}^{\mathrm{a}}$ \\
\hline & Curcumin & & $10.39 \pm 0.23 \mathrm{mg} / \mathrm{g}$ a \\
\hline \multirow{2}{*}{ Boiling } & Total phenols & \multirow{2}{*}{$8.93 \pm 0.64 \mathrm{mg} / \mathrm{g}^{\mathrm{b}}$} & $7.99 \pm 1.55 \mathrm{mg} / \mathrm{g}^{\mathrm{a}-\mathrm{b}}$ \\
\hline & Curcumin & & $7.70 \pm 1.05 \mathrm{mg} / \mathrm{g}^{\mathrm{a}-\mathrm{b}}$ \\
\hline \multirow{2}{*}{ Boiling + Pressure } & Total phenols & \multirow{2}{*}{$11.53 \pm 0.56 \mathrm{mg} / \mathrm{g}^{\mathrm{b}}$} & $6.41 \pm 0.83 \mathrm{mg} / \mathrm{g}^{\mathrm{a}-\mathrm{b}}$ \\
\hline & Curcumin & & $3.95 \pm 0.41 \mathrm{mg} / \mathrm{g}^{\mathrm{c}}$ \\
\hline \multirow{2}{*}{ Microwaving } & Total phenols & \multirow{2}{*}{$10.29 \pm 0.53 \mathrm{mg} / \mathrm{g}^{\mathrm{b}}$} & $5.92 \pm 0.23 \mathrm{mg} / \mathrm{g}^{\mathrm{b}}$ \\
\hline & Curcumin & & $5.98 \pm 0.61 \mathrm{mg} / \mathrm{g}^{\mathrm{b}-\mathrm{c}}$ \\
\hline
\end{tabular}

Mean \pm standard error; superscripted letters indicate statistically-homogenous groups among treatments of each spice.

Fatty acid profiles are in Table 2. In saffron, B decreased the 12:0 lauric acid ( $\mathrm{dp}=0.25)$, but MW $(\mathrm{dp}=-0.16)$ and BP $(\mathrm{dp}=-0.18)$ increased it $(p<0.05)$. The 15:0 pentadecanoic acid was not detected in controls, whereas it was observed after treatments, which can result from their chain-breaking effect on longer fatty acids (Fournier et al., 2006; Özcan et al., 2018). The monounsaturated fatty acids were weakly affected by treatments ( $\omega-7$ 17:1 margaroleic acid increased by B and BP but removed by MW; $\omega-9$ 18:1 oleic acid increased by $\mathrm{B}$ and MW but decreased by BP). In turmeric, treatments increased the $16: 0$ palmitic acid (B dp $=-0.17$, BP dp $=-0.17$, MV dp $=-0.46)$ and removed the $\omega-7$ 17:1 acid $(\mathrm{dp}=0.23)(p<0.05)$, while the $\omega-9$ 18:1 oleic acid weakly differed. Although turmeric and saffron exhibited distinct fatty acid profiles (e.g., saffron contained more saturated acids), heat affected both. In this sense, the saturated fatty acids increased after treatments can depend on the destruction of polyunsaturated ones due to their high susceptibility to heat, with a relative increase of more thermostable lipids (Fournier et al., 2006; Özcan et al., 2018), despite the significant lauric decrease. Furthermore, degradation of long-chain fatty acids induces saturated short- and medium-chain acids. These mechanisms explain heat effects, which were enhanced by pressure (Fournier et al., 2006; Özcan et al., 2018). Moreover, pressurised boiling also affected monounsaturated fatty acids. Nonetheless, these acids present different susceptibility, with oleic acid being more resistant than the others, which promotes its stability and health benefits (Escrich et al., 2011; Schwingshackl \& Hoffmann, 2014). On the other hand, spices responded distinctly. Saffron contained certain resistant $\omega-9(\omega-9$ 18:1, MV dp $=0.01)$ and $\omega-3$ fatty acids $(\omega-318: 3$, MV dp $=0.02)(p>0.05)$, whereas turmeric contained susceptible monounsaturated fatty acids $(\omega-7$ 17:1 acid, $\mathrm{B} \mathrm{dp}=0.23)$ but certain resistant $\omega-6$ fatty acids (e.g. $\omega-6$ 18:2, B dp = -0.13) $(p<0.05)$. Vegetable foods have distinct structural characteristics, which confer differential heat resistance to their lipid constituents (De la Cruz Garcia et al., 2000). Although microwaving conserved chain length to some extent, it did not protect very-long-chain fatty acids. Chatterjee et al. (2009) did not find the impact of radiation processing on the lipid profile of turmeric and suggested a protective role of phenols for lipid integrity. All these events also accounted for relative changes in the fatty acid profile. 
Effect of heat and microwave treatments on phenolic compounds and fatty acids of turmeric (Curcuma longa L.) and saffron (Crocus sativus L.)

Cortez, M. V. et al.

Table 2. Fatty acids of saffron and turmeric expressed as $\%$ of total acids per cooking treatment.

\begin{tabular}{|c|c|c|c|c|}
\hline \multicolumn{5}{|c|}{ Saffron } \\
\hline Fatty acid & Control & Boiling & Boiling+Pressure & Microwaving \\
\hline Saturated & 71 & $82(-0.11)$ & $97\left(-0.26^{*}\right)$ & $85\left(-0.14^{*}\right)$ \\
\hline $4: 0$ & 0.00 & 37.68 & 0.00 & 0.00 \\
\hline $8: 0$ & 0.00 & 0.87 & 10.04 & 0.00 \\
\hline $10: 0$ & 11.82 & 2.29 & 2.73 & 7.80 \\
\hline $11: 0$ & 0.00 & 3.00 & 0.00 & 0.00 \\
\hline $12: 0$ & 51.40 & 26.28 & 69.31 & 66.82 \\
\hline $13: 0$ & 1.36 & 0.00 & 6.89 & 0.00 \\
\hline $14: 0$ & 0.50 & 2.87 & 2.01 & 0.92 \\
\hline $15: 0$ & 0.00 & 0.50 & 2.55 & 1.55 \\
\hline $16: 0$ & 5.62 & 4.55 & 2.95 & 5.47 \\
\hline $17: 0$ & 0.00 & 0.00 & 0.00 & 0.00 \\
\hline $18: 0$ & 0.03 & 2.56 & 0.22 & 0.59 \\
\hline $20: 0$ & 0.00 & 0.78 & 0.72 & 1.09 \\
\hline $22: 0$ & 0.00 & 0.00 & 0.00 & 0.30 \\
\hline $24: 0$ & 0.00 & 0.52 & 0.00 & 0.39 \\
\hline Monounsaturated & 2 & $8(-0.06)$ & $1(0.01)$ & $4(-0.02)$ \\
\hline$\omega-514: 1$ & 0.00 & 0.04 & 0.00 & 0.08 \\
\hline$\omega-7 \quad 16: 1$ & 0.00 & 0.00 & 0.00 & 1.24 \\
\hline$\omega-717: 1$ & 0.13 & 1.27 & 0.78 & 0.00 \\
\hline$\omega-918: 1$ & 1.89 & 3.52 & 0.17 & 2.74 \\
\hline$\omega-1120: 1$ & 0.00 & 3.46 & 0.00 & 0.00 \\
\hline Polyunsaturated & 27 & $10(0.17 *)$ & $2\left(0.25^{*}\right)$ & $11\left(0.16^{*}\right)$ \\
\hline$\omega-618: 2$ & 20.59 & 5.36 & 1.17 & 5.72 \\
\hline$\omega-618: 3$ & 0.03 & 2.24 & 0.14 & 0.75 \\
\hline$\omega-318: 3$ & 6.35 & 1.97 & 0.30 & 4.20 \\
\hline$\omega-620: 2$ & 0.00 & 0.00 & 0.00 & 0.04 \\
\hline$\omega-620: 3$ & 0.00 & 0.16 & 0.09 & 0.00 \\
\hline$\omega-320: 3$ & 0.00 & 0.00 & 0.00 & 0.23 \\
\hline$\omega-320: 5$ & 0.00 & 0.00 & 0.00 & 0.00 \\
\hline$\omega-322: 5$ & 0.23 & 0.31 & 0.00 & 0.04 \\
\hline$\omega-622: 4$ & 0.00 & 0.00 & 0.00 & 0.00 \\
\hline Total & 100 & 100 & 100 & 100 \\
\hline \multicolumn{5}{|c|}{ Turmeric } \\
\hline Fatty acid & Control & Boiling & Boiling+Pressure & Microwaving \\
\hline Saturated & 39 & $62\left(-0.23^{*}\right)$ & $40(-0.01)$ & $72(-0.33 *)$ \\
\hline $4: 0$ & 0.00 & 0.00 & 0.00 & 0.00 \\
\hline $8: 0$ & 0.00 & 0.26 & 5.48 & 0.00 \\
\hline $10: 0$ & 18.93 & 0.00 & 0.00 & 0.00 \\
\hline $11: 0$ & 0.00 & 0.26 & 2.16 & 0.00 \\
\hline $12: 0$ & 0.00 & 0.00 & 0.00 & 7.19 \\
\hline $13: 0$ & 0.00 & 0.00 & 0.87 & 0.00 \\
\hline $14: 0$ & 6.20 & 3.24 & 1.73 & 10.70 \\
\hline $15: 0$ & 0.89 & 0.44 & 0.00 & 0.00 \\
\hline $16: 0$ & 7.99 & 25.34 & 24.99 & 54.31 \\
\hline $17: 0$ & 5.33 & 0.00 & 0.00 & 0.00 \\
\hline $18: 0$ & 0.00 & 32.37 & 5.26 & 0.00 \\
\hline $20: 0$ & 0.00 & 0.00 & 0.00 & 0.00 \\
\hline $22: 0$ & 0.00 & 0.00 & 0.00 & 0.00 \\
\hline $24: 0$ & 0.00 & 0.00 & 0.00 & 0.00 \\
\hline Monounsaturated & 43 & $5(0.38 *)$ & $12(0.31 *)$ & $17(0.26 *)$ \\
\hline$\omega-514: 1$ & 3.85 & 0.00 & 0.00 & 0.00 \\
\hline$\omega-7 \quad 16: 1$ & 2.96 & 0.00 & 0.00 & 3.52 \\
\hline$\omega-717: 1$ & 23.37 & 0.00 & 0.00 & 0.00 \\
\hline$\omega-918: 1$ & 12.43 & 5.26 & 11.83 & 13.90 \\
\hline$\omega-1120: 1$ & 0.00 & 0.00 & 0.00 & 0.00 \\
\hline Polyunsaturated & 18 & $33\left(-0.15^{*}\right)$ & $48(-0.30 *)$ & $10(0.08)$ \\
\hline$\omega-618: 2$ & 0.30 & 12.85 & 6.58 & 5.69 \\
\hline$\omega-618: 3$ & 0.00 & 0.00 & 0.00 & 4.69 \\
\hline$\omega-3 \quad 18: 3$ & 0.00 & 0.00 & 0.00 & 0.00 \\
\hline$\omega-620: 2$ & 7.10 & 0.00 & 26.32 & 0.00 \\
\hline$\omega-620: 3$ & 0.00 & 2.45 & 13.91 & 0.00 \\
\hline$\omega-320: 3$ & 0.30 & 0.00 & 0.00 & 0.00 \\
\hline$\omega-320: 5$ & 0.30 & 0.00 & 0.00 & 0.00 \\
\hline$\omega-322: 5$ & 9.76 & 17.53 & 0.87 & 0.00 \\
\hline$\omega-622: 4$ & 0.30 & 0.00 & 0.00 & 0.00 \\
\hline Total & 100 & 100 & 100 & 100 \\
\hline
\end{tabular}

Differences in proportions -dp- respect to control are given between parenthesis with * indicating $p<0.05$. 
The bioactivity of fatty acids and polyphenols does not depend only on the quantity provided by a dietary source. It is also determined by the molecular type (i.e., a qualitative characteristic), which allows compounds to be physiologically-active and functional at low concentrations, which is relevant given that the spices can be added to foods with a poor content of these bioactive compounds (Calder, 2015; Bagetta et al., 2020).

\section{Conclusion}

Cooking affects nutritional quality, thus, it is necessary to identify optimal methods that preserve healthpromoting properties of foods and their ingredients. Pressurised boiling and microwaving caused the loss of phenolic compounds, whereas boiling preserved them in turmeric. In this sense, both spices exhibited different susceptibility to heat, with saffron showing a greater loss of compounds than turmeric.

Turmeric had a better lipid profile than saffron with increased unsaturated fatty acids even after heat treatments. The risk of losing this unsaturated profile and some specific fatty acids by the heat treatments was found. Therefore, the election of the cooking method will depend on nutritional goals, which involve the use of fatty acids under different health conditions.

\section{Acknowledgements}

Research funds were provided by Universidad Nacional de Córdoba [Grant $n^{\circ}$ SECYT-UNC 472/2018], which was not involved in the study design, data management or article writing and submission. A native English speaker has revised this article.

\section{References}

Bagetta, D., Maruca, A., Lupia, A., Mesiti, F., Catalano, R., Romeo, I., Moraca, F., Ambrosio, F. A., Costa, G., Artese, A., Ortuso, F., Alcaro, S., \& Rocca, R. (2020). Mediterranean products as promising source of multi-target agents in the treatment of metabolic syndrome. European Journal of Medicinal Chemistry, 186, 111903. PMid:31787360.

Calder, P. C. (2015). Functional roles of fatty acids and their effects on human health. Journal of Parenteral and Enteral Nutrition, 39(1, Suppl.), 18S-32S. PMid:26177664. http://dx.doi.org/10.1177/0148607115595980

Canalis, A. M., Defagó, M. D., \& Soria, E. A. (2012). Perfil farmaconutricional de azafrán y cúrcuma: Identificación de compuestos lipídicos y fenólicos con potencial xenohormético. Saarbrücken: Editorial Académica Española.

Chatterjee, S., Variyar, P. S., \& Sharma, A. (2009). Stability of lipid constituents in radiation processed fenugreek seeds and turmeric: Role of phenolic antioxidants. Journal of Agricultural and Food Chemistry, 57(19), 9226-9233. PMid:19769367. http://dx.doi.org/10.1021/jf901642e

Choi, W., Lim, H. W., \& Lee, H. Y. (2014). Effect of balanced low pressure drying of Curcuma longa leaf on skin immune activation activities. Bio-Medical Materials and Engineering, 24(6), 2025-2039. PMid:25226899. http://dx.doi.org/10.3233/BME141012

Cortez, M. V., \& Soria, E. A. (2016). The effect of freeze-drying on the nutrient, polyphenol, and oxidant levels of breast milk. Breastfeeding Medicine, 11(10), 551-554. PMid:27925493. http://dx.doi.org/10.1089/bfm.2016.0102

De la Cruz Garcia, C., Lopez Hernandez, J., \& Simal Lozano, J. (2000). Gas chromatographic determination of the fatty-acid content of heat-treated green beans. Journal of Chromatography A, 891(2), 367-370. PMid:11043798. http://dx.doi.org/10.1016/S0021-9673(00)00674-9

Di Lorenzo, C., Dell'agli, M., Badea, M., Dima, L., Colombo, E., Sangiovanni, E., Restani, P., \& Bosisio, E. (2013). Plant food supplements with anti-inflammatory properties: A systematic review (II). Critical Reviews in Food Science and Nutrition, 53(5), 507-516. PMid:23391017. http://dx.doi.org/10.1080/10408398.2012.691916

Escrich, E., Solanas, M., Moral, R., \& Escrich, R. (2011). Modulatory effects and molecular mechanisms of olive oil and other dietary lipids in breast cancer. Current Pharmaceutical Design, 17(8), 813-830. PMid:21443482. http://dx.doi.org/10.2174/138161211795428902

Fournier, V., Destaillats, F., Juanéda, P., Dionisi, F., Lambelet, P., Sébédio, J. L., \& Berdeaux, O. (2006). Thermal degradation of long-chain polyunsaturated fatty acids during deodorization of fish oil. European Journal of Lipid Science and Technology, 108(1), 33-42. http://dx.doi.org/10.1002/ejlt.200500290

Gregory, M. J., Menary, R. C., \& Davies, N. W. (2005). Effect of drying temperature and airflow on the production and retention of secondary metabolites in saffron. Journal of Agricultural and Food Chemistry, 53(15), 5969-5975. PMid:16028982. http://dx.doi.org/10.1021/jf047989j 
Cortez, M. V. et al.

Jiménez, M., Aguilar, M., Zambrano, M., \& Kolar, E. (2001). Propiedades físicas y químicas del aceite de aguacate obtenido de puré deshidratado por microondas. Revista de la Sociedad Química de México, 45(2), 89-92.

Khatun, M., Eguchi, S., Yamaguchi, T., Takamura, H., \& Matoba, T. (2006). Effect of thermal treatment on radical-scavenging activity of some spices. Food Science and Technology Research, 12(3), 178-185. http://dx.doi.org/10.3136/fstr.12.178

Lai, P. K., \& Roy, J. (2004). Antimicrobial and chemopreventive properties of herbs and spices. Current Medicinal Chemistry, 11(11), 1451-1460. PMid:15180577. http://dx.doi.org/10.2174/0929867043365107

Moshiri, M., Vahabzadeh, M., \& Hosseinzadeh, H. (2015). Clinical applications of saffron (Crocus sativus) and its constituents: A review. Drug Research, 65(6), 287-295. PMid:24848002.

Özcan, M. M., Juhaimi, F. A., \& Uslu, N. (2018). The effect of heat treatment on phenolic compounds and fatty acid composition of Brazilian nut and hazelnut. Journal of Food Science and Technology, 55(1), 376-380. PMid:29358830. http://dx.doi.org/10.1007/s13197-017-2947-3

Pujimulyani, D., Raharjo, S., Marsono, Y., \& Santoso, U. (2012). The effect of size reduction and preparation duration on the antioxidant activity of white saffron (Curcuma mangga Val.). Journal of Food and Pharmaceutical Sciences, 1(1)

Ramos Elizagaray, S. I., Quiroga, P. L., Pérez, R. D., Sosa, C., Pérez, C. A., Bongiovanni, G. A., \& Soria, E. A. (2019). Effect of the aqueous extract of Lantana grisebachii Stuck against bioaccumulated arsenic-induced oxidative and lipid dysfunction in rat splenocytes. Journal of Dietary Supplements, 16(4), 401-407. PMid:29958031.

http://dx.doi.org/10.1080/19390211.2018.1470124

Rodríguez-Neira, L., Lage-Yusty, M. A., \& López-Hernández, J. (2014). Influence of culinary processing time on Saffron's bioactive compounds (Crocus sativus L.). Plant Foods for Human Nutrition, 69(4), 291-296. PMid:25373843. http://dx.doi.org/10.1007/s11130-014-0447-4

Sánchez, A. M., Carmona, M. A., Ordoudi, S. Z., Tsimidou, M., \& Alonso, G. L. (2008). Kinetics of individual crocetin ester degradation in aqueous extracts of saffron (Crocus sativus L.) upon thermal treatment in the dark. Journal of Agricultural and Food Chemistry, 56(5), 1627-1637. PMid:18237133. http://dx.doi.org/10.1021/jf0730993

Sánchez, A. M., Carmona, M., Jarén-Galán, M., Mosquera, M. I., \& Alonso, G. L. (2011). Picrocrocin kinetics in aqueous saffron spice extracts (Crocus sativus L.) upon thermal treatment. Journal of Agricultural and Food Chemistry, 59(1), 249-255. PMid:21141822. http://dx.doi.org/10.1021/jf102828v

Schneider, C., Gordon, O. N., Edwards, R. L., \& Luis, P. B. (2015). Degradation of curcumin: From mechanism to biological implications. Journal of Agricultural and Food Chemistry, 63(35), 7606-7614. PMid:25817068.

http://dx.doi.org/10.1021/acs.jafc.5b00244

Schwingshackl, L., \& Hoffmann, G. (2014). Monounsaturated fatty acids, olive oil and health status: A systematic review and meta-analysis of cohort studies. Lipids in Health and Disease, 13(1), 154. PMid:25274026. http://dx.doi.org/10.1186/1476-511X13-154

Serrano-Díaz, J., Sánchez, A. M., Alvarruiz, A., \& Alonso, G. L. (2013). Preservation of saffron floral bio-residues by hot air convection. Food Chemistry, 141(2), 1536-1543. PMid:23790949. http://dx.doi.org/10.1016/j.foodchem.2013.04.029

Shehzad, A., Qureshi, M., Anwar, M. N., \& Lee, Y. S. (2017). Multifunctional curcumin mediates multitherapeutic effects. Journal of Food Science, 82(9), 2006-2015. PMid:28771714. http://dx.doi.org/10.1111/1750-3841.13793

Suresh, D., Manjunatha, H., \& Srinivasan, K. (2007). Effect of heat processing of spices on the concentrations of their bioactive principles: Turmeric (Curcuma longa), red pepper (Capsicum annuum) and black pepper (Piper nigrum). Journal of Food Composition and Analysis, 20(3-4), 346-351. http://dx.doi.org/10.1016/j.jfca.2006.10.002

Yang, H., Du, Z., Wang, W., Song, M., Sanidad, K., Sukamtoh, E., Zheng, J., Tian, L., Xiao, H., Liu, Z., \& Zhang, G. (2017). Structure-activity relationship of curcumin: Role of the methoxy group in anti-inflammatory and anticolitis effects of curcumin. Journal of Agricultural and Food Chemistry, 65(22), 4509-4515. PMid:28513174. http://dx.doi.org/10.1021/acs.jafc.7b01792 Zhang, Z., Wang, C. Z., Wen, X. D., Shoyama, Y., \& Yuan, C. S. (2013). Role of saffron and its constituents on cancer chemoprevention. Pharmaceutical Biology, 51(7), 920-924. PMid:23570520. http://dx.doi.org/10.3109/13880209.2013.771190

Funding: Universidad Nacional de Córdoba. Grant n SECYTUNC 472/2018. 